\title{
EDITORIAL
}

\section{The legacy of development and psychopathology}

\author{
DANTE CICCHETTI ${ }^{a, b}$ \\ ${ }^{a}$ University of Minnesota Institute of Child Development; and ${ }^{b}$ University of Rochester Mt. Hope Family Center
}

The year 2013 marks the 25th anniversary of the publication of the first issue and volume of Development and Psychopathology in 1989. This Special Issue commemorates the founding of the Journal a quarter of a century ago. Articles were commissioned from a group of scientists on topics that represented major and diverse areas within the field of developmental psychopathology. The contributions that were solicited encapsulated the journey that Development and Psychopathology, the flagship journal for the field of developmental psychopathology, has taken over the past 25 years.

Authors were invited to write a paper explicating the major contributions made to date in their research area and to suggest future directions that theoretical and empirical investigations must take in order to address the challenging issues that lie ahead. In addition, I stated that these papers should be forward thinking and visionary in ambition so that they may serve as a future guide to developmental scientists. In essence, I sought contributions that were conceptual, opinion driven, and innovative. These papers were to provide a blueprint for future basic empirical research, translational research, and social policy implications.

The initial issue of Development and Psychopathology in 1989 contained five papers and a brief editorial. The inaugural volume, published quarterly, contained fewer than 400 pages. Over the past 25 years, the journal has grown in annual frequency and page length. This year ushered in the publication of five issues yearly; the number of pages, and consequently the number of articles per issue and year, has increased greatly. Development and Psychopathology now has the capacity to publish 1800-1900 pages per volume.

Since its inception, Development and Psychopathology has published Special Issues. This Special Issue marks the 47th in the history of the Journal. The topics of these Special Issues have been diverse and cutting-edge, often introducing

My work on this Special Issue was funded by the Jacobs Foundation and by the Spunk Fund, Inc. I am very grateful for their support.

Address correspondence and reprint requests to: Dante Cicchetti, Institute of Child Development, University of Minnesota, 51 East River Road, Minneapolis, MN 55455; E-mail: cicchett@umn.edu. scientific concepts, issues, and innovations before they have become prominent in developmental science or in other disciplines. As a fledgling journal, the publication of these Special Issues helped to facilitate its scientific impact above journals in developmental science that had a much longer history. Articles published in Development and Psychopathology have been among the landmark theoretical, review, and empirical papers of the past quarter century. A major goal of these Special Issues has been to not overlook the forest for the trees. Visionary and creative thinking are encouraged, as is the quest for innovative contributions.

As I noted in earlier publications (Cicchetti, 1984b, 1990, 1993), developmental psychopathology is inherently an integrative, multidisciplinary science. Virtually every corner of the social and biological sciences has contributed to developmental psychopathology (Cicchetti \& Sroufe, 2000). Moreover, since its inception the Journal has been committed to breaking down barriers between basic and translational research, between research and practice, and between behavioral and biological sciences. Over time, the Journal and field have become increasingly multilevel. There has been a growing recognition regarding the importance of conducting multiple levels of analysis research on risk, psychopathology, resilience, and intervention outcome (Cicchetti \& Curtis, 2007; Cicchetti \& Dawson, 2002; Cicchetti \& Gunnar, 2008; Masten, 2007; Toth, Gravener-Davis, Guild, \& Cicchetti, 2013 [this issue]). A key to future progress and advances in the field rests upon the continued emphasis on the concept of development, regardless of the domain or level of analysis employed (Cicchetti \& Sroufe, 2000; Sroufe, 2013 [this issue]). Whatever challenges may be ahead for developmental psychopathology, it is essential that development remain at the forefront of scientific conceptualizations and the design of investigations (Rutter \& Sroufe, 2000; Sroufe \& Rutter, 1984).

I owe a great deal of gratitude to former Deputy Editor Barry Nurcombe, the Associate Editors, and the Editorial Board members who have contributed to the emergence of Development and Psychopathology as a highly respected scientific journal. Cambridge University Press has also been very supportive of the future directions the Journal has em- 
barked upon over the years. As a result, as Editor I have had the freedom to help to shape the field of developmental psychopathology.

Although I was the Founding Editor of Development and Psychopathology in 1989, the processes leading to the publication of this Journal have a much longer history. As a graduate student at Minnesota, I taught an undergraduate honors seminar on developmental psychopathology for 3 years, served as Alan Sroufe's Teaching Assistant in his large undergraduate course on the topic, and cotaught the graduate seminar on developmental psychopathology with Alan Sroufe at the Institute of Child Development during my last year of graduate school in 1977.

The behavioral sciences editor at Cambridge University Press at that time was Susan Milmoe. In my first year as an Assistant Professor at Harvard, Susan asked me if I had any ideas that I might be interested in proposing to Cambridge University Press. I suggested a journal on developmental psychopathology, and she was quite surprised. She said she thought I was too young to take on such a project and that I should focus on getting my empirical papers published. In retrospect, she gave me very wise counsel.

Several years later, when I was Associate Professor at Harvard, and after I had edited the Special Issue of Child Development on developmental psychopathology (Cicchetti, 1984a), Susan and I revisited the prospect of the journal we had discussed previously with me as the Editor. I always felt, even from my initial suggestion that was not enacted, that Susan thought I had a good idea and that she believed I could succeed. I wrote the proposal to initiate the Journal and sent it on to Cambridge University Press in late 1985 as I was leaving Harvard for the University of Rochester.

\section{References}

Cicchetti, D. (Ed.). (1984a). Developmental psychopathology [Special Issue]. Child Development, 55, 1-314.

Cicchetti, D. (1984b). The emergence of developmental psychopathology. Child Development, 55, 1-7.

Cicchetti, D. (1990). A historical perspective on the discipline of developmental psychopathology. In J. Rolf, A. Masten, D. Cicchetti, K. Nuechterlein, \& S. Weintraub (Eds.), Risk and protective factors in the development of psychopathology (pp. 2-28). New York: Cambridge University Press.

Cicchetti, D. (1993). Developmental psychopathology: Reactions, reflections, projections. Developmental Review, 13, 471-502.

Cicchetti, D., \& Curtis, W. J. (Eds.). (2007). A multilevel approach to resilience [Special Issue]. Development and Psychopathology, 19, 627955.

Cicchetti, D., \& Dawson, G. (Eds.). (2002). Multiple levels of analysis [Special Issue]. Development and Psychopathology, 14, 417-666.

Cicchetti, D., \& Gunnar, M. R. (Eds.). (2008). Integrating biological processes into the design and evaluation of preventive interventions [Special Issue]. Development and Psychopathology, 20, 737-1021.

Cicchetti, D., \& Sroufe, L. A. (2000). The past as prologue to the future: The times, they've been a changin'. Development and Psychopathology, 12, $255-264$.
Reviews came back in 1987, and I signed a contract with Cambridge. Papers were submitted to Development and Psychopathology for the first time in 1988. The journey leading toward the publication of the first issue is a testimony to the importance of persistence and adherence to a belief in one's passions.

The past 25 years as Editor of Development and Psychopathology has been a labor of love. The field of developmental psychopathology has made major contributions to understanding mental health, psychopathology, and resilience. Many of the papers that have contributed to these advances have appeared in this Journal. I am optimistic that the principles of developmental psychopathology (Cicchetti \& Toth, 2009) will provide a much needed conceptual scaffolding for addressing future challenges, as well as for fostering an increased synergy among basic research, translational research, and the implementation of evidence-based treatment programs.

As I envision the next 25 years for Development and Psychopathology, I anticipate an era of continued innovative advances and successful scientific triumphs over challenges that continue to confront individuals struggling with risk and psychopathology throughout their lives. I am honored to have guided the Journal out of infancy, through adolescence, and into adulthood. I am also gratified that many young scholars who began their publishing careers in this Journal have blossomed into leading scientists in the field. I invite individuals at all stages of their careers to continue the momentum that has been generated by over two decades of publications in Development and Psychopathology. Past and future contributions made by articles published in this Journal have advanced the well-being of society far beyond the academic arena.

Cicchetti, D., \& Toth, S. L. (2009). The past achievements and future promises of developmental psychopathology: The coming of age of a discipline. Journal of Child Psychology and Psychiatry, 50, 16-25.

Masten, A. S. (Ed.). (2007). The Minnesota symposia on child psychology: Vol. 34. Multilevel dynamics in developmental psychopathology. Mahwah, NJ: Erlbaum.

Rutter, M., \& Sroufe, L. A. (2000). Developmental psychopathology: Concepts and challenges. Development and Psychopathology, 12, 265-296.

Sroufe, L. A. (2013). The promise of developmental psychopathology: Past and present. Development and Psychopathology, 25(4, Pt. 2), 12151224.

Sroufe, L. A., \& Rutter, M. (1984). The domain of developmental psychopathology. Child Development, 55, 17-29.

Toth, S. L., Gravener-Davis, J. A., Guild, D. J., \& Cicchetti, D. (2013). Relational interventions for child maltreatment: Past, present, and future perspectives. Development and Psychopathology, 25(4, Pt. 2), 16011617. 